\title{
INFLUENCE OF COMPOST TEA, AZOLLA AND YEAST ON GROWTH OF WHEAT IN SALINE SOIL
}

\author{
Amal, E. Hanna, Reda M. EI - Shahat and Mounira, M. Beshara
}

Soils \& Water and Environ. Res. Inst., Agric. Res. Center, Giza, Egypt.

\begin{abstract}
Two field experiments were carried out to study the effect of compost tea, Azolla and yeast alone or mixed with different rates from urea fertilizers on soil properties and wheat productivity under saline soil condition in Sahl El Hossinia, El - Sharkia Governorate during two winter seasons of $2008-2009$ and 2009 -2010. Urea rates (50 and $75 \mathrm{Kg} \mathrm{N}$ $\mathrm{Fed}^{-1}$ ). The results indicated that increasing mineral nitrogen dose of application from 50 to $75 \mathrm{Kg} \mathrm{N} \mathrm{Fed}^{-1}$ with compost tea led to increase the counts of total bacteria and cyanobacteria. Therefore increase, the rate of respiration and subsequently increased the amounts of evaluated $\mathrm{CO}_{2}$ and also increased both dehydrogenase and nitrogenase activities. In all treatments decreased soil $\mathrm{pH}$ and $\mathrm{EC}$ as a result of improving soil physical properties and activity microorganisms compared with control treatments. The highest organic matters were obtained with application of $T_{11}, T_{12}, T_{9}, T_{10}$ and $T_{3}$. Data showed that nitrogen, phosphorus and potassium soil content were significantly increased when application with $\mathrm{T}_{11}$ over all treatments. The highest NPK contents were 114.50, 6.18 and $245 \mathrm{ppm}$ respectively. Application of treatment $\mathrm{T}_{12}(50 \mathrm{Kg} \mathrm{N}+$ Azolla + yeast + compost tea) non - significant increase in plant height with $\mathrm{T}_{7}\left(75 \mathrm{Kg} \mathrm{N}+\right.$ compost tea) and $\mathrm{T}_{9}$ $\left(75 \mathrm{Kg} \mathrm{N}+\right.$ Azolla + yeast) giving $97.3,96.60$ and $99.64 \mathrm{~cm} \mathrm{plant}^{-1}$. The treatment of compost tea addition with different levels of urea ( 75 and $50 \mathrm{Kg} \mathrm{N}^{-\mathrm{Fed}^{-1}}$ ) increased the plant high, grain yield and the weight of 1000 grains and also increased plant dry weight and straw yield compared the control $\left(\mathrm{T}_{1}\right.$ and $\left.\mathrm{T}_{2}\right)$. However, $\mathrm{T}_{12}$ treatment $(50 \mathrm{Kg} \mathrm{N}+$ Azolla + yeast + compost tea $)\left(485.82 / \mathrm{m}^{-2}\right.$ grain $)$ giving highest recorded for all treatments accept $\mathrm{T}_{11}\left(75 \mathrm{Kg} \mathrm{N}+\right.$ Azolla + yeast + compost tea) giving $499.78 \mathrm{~g} / \mathrm{m}_{2}$. The highest value $T_{11}$ (1000 grain weight) was significantly higher than all tested treatments. Both of $T_{9}$ and $T_{12}$ of these high values were significantly higher than the control treatment. Higher value of $\mathrm{P}$ and $\mathrm{K}$ concentrations for wheat grain and straw were achieved with the application $\mathrm{T}_{11}$ and $\mathrm{T}_{9}$ treatments than the other treatments. The recorded values of $\mathrm{N}, \mathrm{P}$ and $\mathrm{K}$ concentration by grains were $1.85,0.78$ and $1.82 \%$ for soil treated with compost tea combination ( $75 \mathrm{Kg} \mathrm{N} \mathrm{Fed}^{-1}$ ).
\end{abstract}

Key words: Compost tea, Azolla, yeast, microorganisms, soil salinity, wheat production.

\section{Introduction}

Salinity and soil nutrient deficiencies are the main factors reducing plant productivity in arid and semi - arid areas. Among the essential elements, nitrogen is usually the most growth limiting plant nutrient in saline or non - saline soils. 
The compost can be a very good organic amendment in saline agriculture as well as, for reclamation of salt - affected soils ( Zaka, et al., 2003 ). Compost tea is emerging as a crop protection tool for organic agriculture for a number of reasons, It contains microorganisms which can reduce incidence of foliar and / or soil borne diseases, and nutrients contented in compost tea which support the survival and proliferation of microorganisms. It contains nutrients (extracted from compost) in a readily available form (Al - Kahal, et al., 2009). Organic fertilizers in comparison of the chemical fertilizers have lower nutrient content and are slow release but they are as effective as chemical fertilizers over longer periods of use (Naguib, 2011). Organic manures can serve as alternative to mineral fertilizers for improving soil structure (Dauda et al., 2008) and microbial biomass (Suresh $\boldsymbol{e t}$ al., 2004). These are also used to provide biological control against various plant pathogens (Hoitink and Grebus, 1994).

Active dry yeast is a natural safety biofertilizers causes various promotive effects on plants. It is considered as a natural source of cytokinins which simulates cell division and enlargement as well as the synthesis of protein, nucleic acid and B- vitamin. (Amer, 2004). It also releases $\mathrm{CO}_{2}$ which reflected in improving net photosynthesis (Kurtzman, 2005).

Dry yeast and compost tea were used in growing medium of Borago plants. The results revealed that $20 \mathrm{~L} . /$ fed. of compost tea significantly increased plant height, fresh and dry weight of aerial parts and flowers and number of branches and suckers, adding dry yeast at the rate of $6 \mathrm{~g} / \mathrm{L}$ was the most effective on growth parameters and oil \% ( Ezz EI - Din and Hendawy, 2010 ).

Reda et al., 2011 reported that Azolla growth rate is very high ( $3-5$ days ) under optimal conditions. Azolla not only increase rice yield but also improve soil fertility. They found that use of different bio - fertilizers including Azolla, along with a low input of chemical $-\mathrm{N}$ fertilizer is useful for increasing rice yield. Norton (2004) suggested that, use of Azolla species in rice fields will keep the floodwater $\mathrm{pH}$ low and hence this led to fewer losses of applied fertilizers, and the growth of Azolla is benefit if the soil has a high available $\mathrm{P}$ content and low $\mathrm{P}$ sorption capacity. Azolla incorporated to soil, improves soil structure, increasing organic matter, total fixed nitrogen, phosphorus and other nutrients into soil. Awodun (2008) studied potentiality of Azolla to improve soil physical properties such as bulk density and porosity. In addition, they reported its ability to improve soil chemical properties ( organic matter, $\mathrm{N}, \mathrm{P}, \mathrm{K}, \mathrm{Ca}, \mathrm{Mg}$ and $\mathrm{Na}$ ).

Biofertilizers are microbial inoculants consisting of living cells of microorganisms like bacteria, algae and fungi alone or combination which may help in increasing crop productivity. Biological activities are markedly enhanced by microbial interactions in the rhizosphere of plants (Tilak and Reddy, 2006). Application of organic and biofertilizers as substitute for inorganic fertilizers in order to grow the medicinal and aromatic plants, should not be considered as a simple objective and short term benefits, but as a mean to improve environmental conditions and human health. (Shahram and Kourosh, 2011).

Egyptian J. of Phycol. Vol. 13, $2012 \quad$ - 76 - 
The aim of the current study is to evaluate the effect of compost tea, Azolla, yeast and urea nitrogen on wheat yield and yield components. Growing in saline soil as well as soil biological activity, total bacteria and cyanobacterial count, $\mathrm{Co}_{2}$ evoluation, dehydrogenase and nitrogenase activity under saline soil condition.

\section{Material and Methods}

Two field experiments were carried out at a farm located at sahl El. Hossinia, El. Sharkia Governorate during two successive winter seasons of 2008-2009 and $2009-2010$ to study the role of compost tea, Azolla and combined with different rate of mineral nitrogen ( urea $46.5 \%$ ) 50 and $75 \mathrm{Kg} \mathrm{N} \mathrm{Fed}^{-1}$ on saline soil, biological activity, soil properties and wheat productivity.

\section{Soil analysis}

The experiment filed soil was sampled initially before and after wheat grown conducting the experiment to determine its physical and chemical analyses according to Jackson (1976). The results of these analyses are shown in Table (1).

\section{Preparation of compost tea}

An aerated compost tea ( ACT ) from composted corn stalks, rice straw and plant resudwal. Mature compost was suspended in a barrel of water for 7 days to produce compost extract. A $50 \mathrm{~L}$ tank is fitted with air bubblers that are attached to an aquarium type aeration pump (Ingham, 2005). The tank was half filled with water and air was passed through it for approximately $10-20$ minutes from the air bubbles. Compost extract is the added to fill the tank. The aerator provides continuous flow of air. An aerated compost tea was aerobically brewed for 15 days but it can be brewed for longer if desired. Soluble macro and micro nutrients of used compost tea. EC 1.01, pH 6.33, Available nitrogen $200 \mathrm{ppm}, \mathrm{P}$ 10 ppm, K 211 ppm, Ca 69 ppm, Mg 106 ppm, Fe 59 ppm and Z 17 ppm.

\section{Azolla extract and yeast}

Azolla pinnata, yeast and compost tea were kindly obtained from Agric. Microbiology, Res. Dept., soils \& water and Environment . Res. Inst. ( SWERI )., Agric., Center ( ARC ). Giza Egypt. Wet Azolla were hardly crushed mixed with water $(1: 1 \mathrm{w} / \mathrm{v})$ and blended to obtain homogenous suspension. The obtained suspension was filtrated through cotton cloth. The obtained filtrated represents Azolla extract to be used as foliar spray.

Active dry yeast $\left(6 \mathrm{~g} \mathrm{~L}^{-1}\right)$ were dissolved in water flowed by adding sugar at ratio $1: 1$ and kept for activation and reproduction of yeast before application on the plant. 
Table ( 1 ) : Physical and chemical characteristics of the experimental soil.

\begin{tabular}{|c|c|c|}
\hline \multirow{5}{*}{ Physical analysis } & Course sand $\%$ & 10.79 \\
\hline & Fin e sand $\%$ & 22.15 \\
\hline & Silt $\%$ & 9.5 \\
\hline & Clay \% & 47.56 \\
\hline & Texture & Clay loam \\
\hline \multirow{4}{*}{ Chemical analysis } & PH $(1: 2.5)$ & 8.17 \\
\hline & $\mathrm{EC}(\mathrm{ds} / \mathrm{m})$ & 14.15 \\
\hline & O.M\% & 0.67 \\
\hline & $\mathrm{Ca} \mathrm{Co}_{3} \%$ & 7.15 \\
\hline \multirow{4}{*}{ Cations $\left(\mathrm{mg}^{-1}\right)$} & $\mathrm{Ca}^{++}$ & 15.49 \\
\hline & $\mathrm{Mg}^{++}$ & 18.71 \\
\hline & $\mathrm{Na}^{+}$ & 192 \\
\hline & $\mathrm{K}^{+}$ & 1.52 \\
\hline \multirow{3}{*}{ Anion $\left(\mathrm{mg}^{-1}\right)$} & $\mathrm{So}_{4}^{-}$ & 31.1 \\
\hline & $\mathrm{CL}^{-}$ & 188 \\
\hline & $\mathrm{HCO}_{3}$ & 8.62 \\
\hline \multirow{7}{*}{ Available nutrient $\mathrm{mg} \mathrm{Kg}^{-}$} & $\mathrm{Cu}$ & 0.05 \\
\hline & $\mathrm{Zn}$ & 0.69 \\
\hline & $\mathrm{Mn}$ & 3.51 \\
\hline & $\mathrm{Fe}$ & 1.69 \\
\hline & $\mathrm{N}$ & 59.19 \\
\hline & $\mathrm{P}$ & 4.9 \\
\hline & $\mathrm{K}$ & 168 \\
\hline
\end{tabular}

\section{Field experiment:}

Two field experiments were carried out on salt affected soil ( EC $14.15 \mathrm{dS}$ $/ \mathrm{m}^{-1}$ ) at Sahl El-hossinia, during two winter seasons 2008 - 2009 and 2009 2010 to evaluate the application of compost tea, Azolla and yeast in the presence of urea ( 75 and $50 \mathrm{Kg} \mathrm{N} \mathrm{Fed}^{-1}$ ) on growth and yield of wheat plant seeds ( sakha 69) . Wheat seeds kindly obtained from Crop Res. Inst., Agric. Res. Center, Giza, Egypt.

All treatments under investigation were arranged in a complete randomized blook design according to Gomez and Gomez ( 1984 ) with three replicates. Wheat plants were exposed to foliar spraying by compost tea, Azolla extract and yeast extract. Urea was applied in two doses ( 75 and $50 \mathrm{Kg} \mathrm{N} \mathrm{Fed}^{-1}$ at 15 and 45 days after sowing ), at the doses of 75 and $50 \mathrm{Kg} \mathrm{N}^{-1}$ fed $^{-1}$ individually or in combination with tested treatments. The field was divided into 12 plots with three replicats in the following : 
$\mathrm{T}_{1}=75 \mathrm{Kg} \mathrm{N}-$ urea.

$\mathbf{T}_{2}=50 \mathrm{Kg} \mathrm{N}$ - urea.

$\mathrm{T}_{3}=75 \mathrm{Kg} \mathrm{N}-$ urea + Azolla $\left(5 \mathrm{~L} / \mathrm{m}^{-2}\right)$ Foliar

$\mathrm{T}_{4}=50 \mathrm{Kg} \mathrm{N}-$ urea + Azolla $\left(5 \mathrm{~L} / \mathrm{m}^{-2}\right)$ Foliar

$\mathrm{T}_{5}=75 \mathrm{Kg} \mathrm{N}-$ urea Yeast $\left(2 \mathrm{Kg}\right.$ dry yeast Fed $\left.^{-1}\right)$

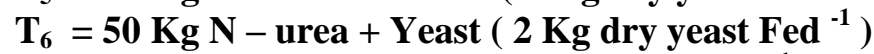

$\mathrm{T}_{7}=75 \mathrm{Kg} \mathrm{N}-$ urea + compost tea $\left(20 \mathrm{~L}_{/} \mathrm{Fed}^{-1}\right)$

$\mathrm{T}_{8}=50 \mathrm{~Kb} \mathrm{~N}-$ urea + Compost tea $\left(20 \mathrm{~L}_{/} \mathrm{Fed}^{-1}\right)$

$\mathrm{T}_{9}=75 \mathrm{Kg} \mathrm{N}-$ urea + Azolla + Yeast .

$\mathrm{T}_{10}=50 \mathrm{Kg} \mathrm{N}-$ urea + Azolla + Yeast .

$\mathrm{T}_{11}=75 \mathrm{Kg} \mathrm{N}-$ urea + Azolla + Yeast + compost tea.

$\mathrm{T}_{12}=50 \mathrm{Kg} \mathrm{N}-$ urea + Azolla + Yeast + compost tea.

The experimental unit ( plot area ) was $3.5 \times 4 \mathrm{~m}^{2}$. The amount of the compost tea, Azolla yeast and all treatments were drivided into three portions ( 21 $-45-65$ days of sowing plants ). Compost tea added at the rate of $20 \mathrm{~L} / \mathrm{Fed}^{-1}$ according to Hendawy et al. ( 2010 )., Azolla $5 \mathrm{~L} / \mathrm{m}_{2}$ and yeast extract ( $2 \mathrm{~kg} \mathrm{Fed}^{-}$ $\left.{ }^{1}\right)$.

In control, the recommended doses of nitrogen (Urea $46.5 \% \mathrm{~N}$ ) 75 and $50 \mathrm{Kg} \mathrm{N} \mathrm{Fed}^{-1}$, phosphorus (Calcium super phosphate $\left(15.5 \% \mathrm{P}_{2} \mathrm{O}_{5}\right), 150 \mathrm{Kg}$

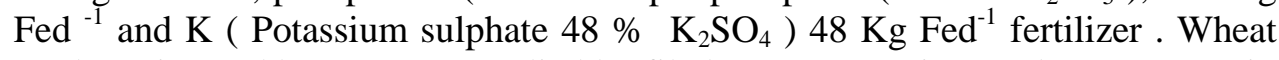
seeds varity (Sakha 69) was supplied by filed Crop Res. Five seeds were sown in every holl with $5 \mathrm{~cm}$ depth. After 18 day of planting, the plant of each hole was thinned to one plant. At harvesting stage, surface soil sample were collected, air dried ground good mixed.

\section{Methods Analysis:}

The collected soil samples before drying were used for determination of soil biological activity, soil total bacterial count ( Vincent, 1970 ), cyanobacteria count ( Allen and Staniar 1968 ), carbon dioxide evolution ( Gaur et al., 1971 ), dehydrogenase (DHA ) ( Casida $\boldsymbol{e t} \boldsymbol{a l} ., 1964$ ) and nitrogenase activity ( Hardy $\boldsymbol{e t}$ al., 1973 ) Soil organic matter was determined according to the methods described by Black ( 1965$)$, pH was measured using $\mathrm{pH}$ meter in soil $(1: 2.5)$ and electrical conductivity ( EC ) were measured in soil pest according to (Jackson, 1976 ). On the before harvesting three plants of each treatment were collected and ovened dried at $70 \mathrm{C}$ and weighed. The oven dried grain and straw were ground $0.5 \mathrm{~g}$ of each sample was suggested according to (Chapman and pratt, 1961). The grain and straw contents of NPK was determined according to Black, (1965). 


\section{Results and Discussion}

In this study will provide information for better source of organic and bio fertilizers to increase the organic fertilizer input and improve the saline soil, plant nutrient, soil biological activity, wheat production and soil properties in saline soil. Two field experiments were carried out during the two seasons.( data mean values of two seasons ).

\section{Population density of soil microorganisms:}

Data in Table (2) showed the effect of compost tea, Azolla and yeast and when applied alone or mixed together on densities of soil microbes in experimental saline soil after wheat harvesting. Nitrogenase activity in wheat rhizosphere zone of root in $\mu$ mole $\mathrm{C}_{2} \mathrm{H}_{4} / \mathrm{g}$ dry soil/hr. and dehydrogenase in $\mu \mathrm{g}$ $\mathrm{TPF} / \mathrm{g}$ dry soil /day after harvisted wheat are presented in Table (2).

Data in Table ( 2 ) indicate that the soil biological activity after wheat harvesting in terms of cyanobacteria count, total bacteria count, $\mathrm{Co}_{2}$ evolution as well as dehydrogenase (DHA) and nitrogenase activities as affected with Azolla, yeast, compost tea and/or nitrogen fertilizer either alone or combined together. All tested soil biological activity parameters under the effect of tested treatments with higher than those of the control treatments. The numbers of total cyanobacteria and bacteria show a positive increasing response to treatments $T_{11}$ and $T_{12}$ treatments. On the other hand, increasing the nitrogen levels from $50 \mathrm{Kg} \mathrm{N}\left(\mathrm{T}_{12}\right)$ up to $75 \mathrm{Kg} \mathrm{N}\left(\mathrm{T}_{11}\right)$ increasing the total cyanobacteria and the total bacteria counts compared to those control $\mathrm{T}_{1}$ and $\mathrm{T}_{2}$ treatments by 75 and $50 \mathrm{Kg} \mathrm{N} \mathrm{Fed}{ }^{-1}$. The highest cyanobacteria and bacteria counts were recorded in response to $\mathrm{T}_{11}$ (Azolla, yeast, compost tea and $75 \mathrm{Kg} \mathrm{N} \mathrm{Fed}^{-1}$ ) inoculation giving $156.36 \times 10^{3}$ and $265.75 \times 10^{5}$ CFU respectively. Inoculation with $2 / 3$ recommended dose of nitrogen based treatment $\left(\mathrm{T}_{12}\right)$ ( Azolla, yeast, compost tea) inoculation in wheat cultivation significantly increased compared to $\mathrm{T}_{2}$ treatment. The treatments received nitrogen only were less in total cyanobacteria and total bacteria count than those received Azolla, yeast, compost tea inoculation. These results are on the line with Rao \& Burns (1990) previously vitamins and plant growth stimulation hormone. In addition, cyanobacteria excrete polysaccharides thereby improving soil aggregation, as well as stimulate some beneficial soil microorganisms. Mandel et al. (1999) reported a significant increase in organic carbon content in the soil due to successive Azolla cropping with rice plant, which in turn increased soil fertility through enhancing the growth and biomass of the soil microorganisms. The highest values during the two seasons were in Table (2). 
Table (2): Effect of compost tea, Azolla and yeast on soil biological activity after wheat harvesting (data mean values of two seasons)

\begin{tabular}{|c|c|c|c|c|c|}
\hline Treatments & $\begin{array}{c}\text { Cyanobacteria } \\
\text { count } \\
\text { CFU.g.d.wt } \\
\text { soil X } \mathbf{1 0}^{\mathbf{3}}\end{array}$ & $\begin{array}{c}\text { Total } \\
\text { count } \\
\text { bacteria } \\
\text { CFU } \\
\text { g.d.wt } \\
\text { soil X } \\
10^{5} \\
\end{array}$ & $\begin{array}{c}\mathrm{Co}_{2} \\
\text { evolution } \\
\mathrm{mg} \mathrm{CO}_{2} \\
\mathbf{1 0 0} \mathrm{g} \\
\text { soil }^{-1}\end{array}$ & $\begin{array}{c}\text { Dehydrogenase } \\
\text { activity Ug } \\
\text { TPF 100g soil. } \\
\text { Day }\end{array}$ & $\begin{array}{c}\text { Nitrogenase } \\
\text { activity } \mathrm{U} \\
\mathrm{Mol} \mathrm{C}_{2} \mathrm{H}_{4} \mathbf{g} \\
\text { dry wet soil } \\
\text { /hr }\end{array}$ \\
\hline $\mathbf{T}_{0}$ & 8.53 & 31.20 & 75.00 & 21.00 & 35.00 \\
\hline$T_{1}$ & 11.80 & 35.20 & 102.0 & 26.80 & 43.29 \\
\hline $\mathbf{T}_{2}$ & 9.60 & 32.90 & 98.20 & 24.50 & 35.80 \\
\hline $\mathbf{T}_{3}$ & 65.80 & 96.81 & 121.80 & 53.20 & 57.83 \\
\hline $\mathbf{T}_{4}$ & 54.30 & 59.40 & 101.45 & 47.13 & 47.35 \\
\hline $\mathbf{T}_{5}$ & 26.35 & 60.90 & 111.55 & 66.11 & 39.40 \\
\hline$T_{6}$ & 25.40 & 54.20 & 105.75 & 55.15 & 30.20 \\
\hline $\mathbf{T}_{7}$ & 66.75 & 105.86 & 155.20 & 89.90 & 60.60 \\
\hline $\mathbf{T}_{8}$ & 59.18 & 69.41 & 121.00 & 60.40 & 59.18 \\
\hline $\mathbf{T}_{9}$ & 96.30 & 118.00 & 212.45 & 90.95 & 63.36 \\
\hline$T_{10}$ & 80.55 & 86.40 & 140.62 & 81.15 & 60.14 \\
\hline $\mathbf{T}_{11}$ & 156.36 & 265.75 & 254.43 & 98.80 & 96.15 \\
\hline$T_{12}$ & 115.25 & 201.96 & 190.56 & 89.15 & 69.40 \\
\hline
\end{tabular}

Data in table (2) indicated that the treatments of $\mathrm{T}_{11}, \mathrm{~T}_{9}, \mathrm{~T}_{12}$ and $\mathrm{T}_{10}$ increased the $\mathrm{Co}_{2}$ evaluated, dehydrogenase and nitrogenase activities being $254.43,212.45,190.56,140.62 \mathrm{mg} \mathrm{Co}_{2} .100 \mathrm{~g}^{-1}$ soil , $98.80,90.95,89.15$ and $81.15 \mathrm{ug}$.TPF. $100 \mathrm{~g}^{-1}$ soil and $96.15,63.36,69.40$ and $60.14 \mu$ mole $\mathrm{C}_{2} \mathrm{H}_{4} \mathrm{~g}^{-1}$ soil respectively. The same trend was reported by Abd El-Rasoul, et al.,(2004) who reported that inoculation with cyanobacteria increased the soil microbial biomass, which in turn increase $\mathrm{CO}_{2}$ and the DHA as a results of the massive respiration process.

Generally total cyanobacteria and bacteria counts, $\mathrm{Co}_{2}$ evaluation, dehydrogenase and nitrogenase activity were increased by the addition of compost tea with different level of urea $\left(75\right.$ and $50 \mathrm{Kg} \mathrm{N}$. Fed $\left.{ }^{-1}\right)$. Increasing mineral nitrogen dose of application from 50 to $75 \mathrm{Kg} \mathrm{N}_{\text {. }} \mathrm{Fed}^{-1}$ with compost tea led to increase the counts of total bacteria and cyanobacteria, therefore increase the rate of respiration and subsequently increased the amounts of evolved $\mathrm{Co}_{2}$ and also increased both dehydrogenase and nitrogenase activities. On the other hand, result simarlly with ( El - Zeky et al ., 2005 ) . 
It could be concluded that the inoculation of wheat with Azolla, yeast, compost tea are of importance in the view of being used as biofertilizers as well as protecting the environment from pollution and consequently producing a satisfactorynd good wheat yield. Kheder and Farid (2000) demonstrated that the effect of yeast is due to its capability in induction of endogenous hormones like $\mathrm{GA}_{3}$ and IAA. Recently dry yeast is used as an alternative source of growth substances in bioorganic fertilization system.

\section{Yield and yield components:}

Soil chemical properties and fertility conditions are reflected on plant growth, which in turn affect the yield and yield components shown in Table ( 3 ). There was significant increase in plant height with $\mathrm{T}_{9}$ and $\mathrm{T}_{11}$ treatments in both seasons as compared to all the other treatments. High records of plant height being 99.64 and $108.5 \mathrm{~cm}$ plant $^{-1}$ resulted in treatments $\mathrm{T}_{9}$ and $\mathrm{T}_{11}$ respectively.

However, the use of application Azolla, yeast, compost tea alone or in combination mixture showed increase in plant height as compared to the control treatment $\mathrm{T}_{1}$. Application of treatment $\mathrm{T}_{12}(50 \mathrm{Kg} \mathrm{N}+$ Azolla+ yeast+ compost tea) non-significant increase in plant height with $\mathrm{T}_{7}(75 \mathrm{Kg} \mathrm{N}+$ Compost tea) and $\mathrm{T}_{9}\left(75 \mathrm{Kg} \mathrm{N}+\right.$ Azolla+ yeast) giving 97.3, 96.60 and $99.64 \mathrm{~cm} \mathrm{plant}^{-1}$.

\section{Plant dry weight:}

Data in Table (3) indicated that all the treatments gave higher dry weight than the control $\mathrm{T}_{1}(75 \mathrm{Kg} \mathrm{N})$ and $\mathrm{T}_{2}(50 \mathrm{Kg} \mathrm{N})$. The highest records were obtained with $\mathrm{T}_{11}, \mathrm{~T}_{9}$ and $\mathrm{T}_{7}$ treatments giving $2.14,1.94$ and $1.92 \mathrm{Kg} \mathrm{m}^{1}$ respectively. On the other hand, treatment $\mathrm{T}_{12}(50 \mathrm{Kg} \mathrm{N}+$ Azolla+ yeast+ compost tea) was non-significant with treatment $\mathrm{T}_{7}(75 \mathrm{Kg} \mathrm{N}+$ Compost tea) giving $1.92 \mathrm{Kg} \mathrm{m}^{-1}$. Application of treatment $\mathrm{T}_{10}(50 \mathrm{Kg} \mathrm{N}+$ Azolla+ yeast $)$ giving the highest plant dry weight $1.78 \mathrm{Kg} \mathrm{m}^{-1}$ compared to $\mathrm{T}_{3}(75 \mathrm{Kg} \mathrm{N}+$ Azolla) giving $1.68 \mathrm{Kg} \mathrm{m}^{-1}$.

\section{Grain \& Straw yield and 1000 grain weight:}

Data in table (3) indicated the thickness increase in grains and straw yield were determined with treatments $T_{11}$ and $T_{12}$ for grain and $T_{4}$ and $T_{7}$ for straw yields. In addition all tested treatments significantly increased for grain yield over control, but non significantly increased of straw yield over control. Application of $\mathrm{T}_{11}$ and $\mathrm{T}_{12}$ treatments showed highest grain yields $\left(499.78\right.$ and $\left.485.82 \mathrm{~g} / \mathrm{m}^{2}\right)$ as compared with $\mathrm{T}_{1}, \mathrm{~T}_{2}$ treatments $\left(305.15\right.$ and $\left.290.45 \mathrm{~g} / \mathrm{m}^{2}\right)$. However, $\mathrm{T}_{12}$ treatment $(50 \mathrm{Kg} \mathrm{N}+$ Azolla + Yeast + Compost tea $)\left(485.82 / \mathrm{m}^{2}\right.$ grain $)$ giving highest recorded for all treatments accept $\mathrm{T}_{11}(75 \mathrm{Kg} \mathrm{N}+$ Azolla + yeast + compost tea) giving $499.78 \mathrm{~g} / \mathrm{m}^{2}$. El - Howeity et al. (2004) found that inoculation of wheat with diazotrophs bacteria under different levels of nitrogen fertilizer significantly increased shoot, root, dry weights and yield compared to control. Inoculation with $\mathrm{T}_{4}$ treatment $(50 \mathrm{Kg} \mathrm{N}+$ Azolla $)$ and $\mathrm{T}_{7}$ treatment $(75 \mathrm{Kg} \mathrm{N}+$ 
compost tea) giving the highest recorded straw yield $\left(1.02 \mathrm{Kg} / \mathrm{m}^{2}\right)$ non significantly with all tested treatment.

Table (3): Yield and yield components of wheat cultivated in two seasons affected by compost tea, Azolla, yeast and nitrogen sources under saline soil conditions (data are a mean two seasons)

\begin{tabular}{|c|c|c|c|c|c|}
\hline Treatments & $\begin{array}{c}\text { Plant high } \\
(\mathbf{c m})\end{array}$ & $\begin{array}{c}\text { Plant dry } \\
\text { weight } \mathbf{( k g} / \\
\mathbf{m}^{\mathbf{2}} \mathbf{~}\end{array}$ & $\begin{array}{c}\text { Grain yield } \\
\mathbf{( g . ~}^{\mathbf{2})}\end{array}$ & $\begin{array}{c}\text { Straw yield } \\
\left(\mathbf{k g} / \mathbf{m}^{\mathbf{2}} \mathbf{)}\right.\end{array}$ & $\begin{array}{c}\mathbf{( 1 0 0 0} \\
\text { grain }(\mathbf{g})\end{array}$ \\
\hline $\mathbf{T}_{\mathbf{1}}$ & 81.88 & 1.40 & 305.15 & 1.0 & 20.98 \\
\hline $\mathbf{T}_{\mathbf{2}}$ & 78.50 & 1.21 & 290.45 & 0.92 & 19.76 \\
\hline $\mathbf{T}_{\mathbf{3}}$ & 91.80 & 1.68 & 420.30 & 0.95 & 24.94 \\
\hline $\mathbf{T}_{\mathbf{4}}$ & 90.70 & 1.55 & 390.25 & 1.02 & 22.27 \\
\hline $\mathbf{T}_{\mathbf{5}}$ & 85.40 & 1.44 & 326.14 & 0.92 & 23.75 \\
\hline $\mathbf{T}_{\mathbf{6}}$ & 82.60 & 1.32 & 309.20 & 0.97 & 21.55 \\
\hline $\mathbf{T}_{\mathbf{7}}$ & 96.60 & 1.92 & 318.02 & 1.02 & 24.43 \\
\hline $\mathbf{T}_{\mathbf{8}}$ & 94.30 & 1.68 & 323.11 & 0.98 & 22.09 \\
\hline $\mathbf{T}_{\mathbf{9}}$ & 99.64 & 1.94 & 451.42 & 0.95 & 26.10 \\
\hline $\mathbf{T}_{\mathbf{1 0}}$ & 90.17 & 1.78 & 417.70 & 0.94 & 24.21 \\
\hline $\mathbf{T}_{\mathbf{1 1}}$ & 108.5 & 2.14 & 499.78 & 0.89 & 30.17 \\
\hline $\mathbf{T}_{\mathbf{1 2}}$ & 97.3 & 1.92 & 485.82 & 0.91 & 25.81 \\
\hline L.S.D 5\% & 13.49 & 0.168 & 30.750 & N.S & 1.535 \\
\hline
\end{tabular}

Due to 1000 grain weight, results confirmed that all treatments gave significantly higher values over the control treatment. However, the highest 1000 grain weight values were due to $\mathrm{T}_{11}$ treatment $(75 \mathrm{Kg} \mathrm{N}+$ compost tea + Azolla+ yeast) $(30.17 \mathrm{~g}) . \mathrm{T}_{9}$, treatment $\left(75 \mathrm{Kg} \mathrm{N}+\right.$ Azolla+ yeast) $(26.10 \mathrm{~g})$ and $\mathrm{T}_{12}$ treatment $(50 \mathrm{Kg} \mathrm{N}+$ compost tea + Azolla + yeast $)$ giving $(25.81 \mathrm{~g})$ non-significant difference between both of them. The highest value ( 1000 grains weight ) $\mathrm{T}_{11}$ was significantly higher than all tested treatments. Both of $\mathrm{T}_{9}$ and $\mathrm{T}_{12}$ of these high value were significantly higher than the control treatment.

Data in Table ( 3 ) indicated that the treatments of compost tea addition with different levels of urea ( 75 and $50 \mathrm{Kg} \mathrm{N} \mathrm{Fed}^{-1}$ ) increased the plant high , grains yield and increased the weight of 1000 grains and also increased plant dry weight and straw yield compared the control $\left(\mathrm{T}_{1}\right)$ and $\mathrm{T}_{2}$. Hendawy, et al. (2010) revealed that beneficial effect of compost tea on plant may due to its direct nutrients supplying and / or its microbial functions. 


\section{$\mathrm{N}$ - $\mathbf{P}$ and $\mathrm{K}$ contents in grain and straw.}

Results in Table ( 4 ) indicated that N, P and K contents in wheat grain and straw as affected by Azolla, yeast and compost tea applied as foliar application showed pronounced increased than control treatments. Data in Table ( 4 ) showed also that, the highest increased nitrogen content in grain and straw were occurred when the wheat were treated with $\mathrm{T}_{11}$ treatment $(75 \mathrm{Kg} \mathrm{N}+$ Azolla+ yeast+ compost tea) as foliar application giving $1.91 \mathrm{~N} \%$ in grain and $0.95 \mathrm{~N} \%$ in straw. This high amount was relatively caught significantly level in comparison to all treatments except for $\mathrm{T}_{7}$ treatment $(75 \mathrm{Kg} \mathrm{N}+$ compost tea ) for $1.85 \%$ grain nitrogen percentage and $\mathrm{T}_{9}(75 \mathrm{Kg} \mathrm{N}+$ Azolla+ yeast) for straw nitrogen $(0.84)$ percentage. This attitude led to conclude that the use of treatment $\mathrm{T}_{11}$ could economically satisfy the recommended level of nitrogen, $\mathrm{T}_{11}$ application increased significantly all the tested grain and straw nitrogen.

Table (4): Concentration of $N, P$ and $K$ in wheat grain and straw as affected by compost tea, Azolla, yeast and nitrogen fertilizers in saline soil (data was a mean two sesons)

\begin{tabular}{|c|c|c|c|c|c|c|}
\hline \multirow{2}{*}{ Treatments } & \multicolumn{3}{|c|}{ Grain } & \multicolumn{3}{c|}{ Straw } \\
\cline { 2 - 7 } & $\mathbf{N \%}$ & $\mathbf{P \%}$ & $\mathbf{K \%}$ & $\mathbf{N \%}$ & $\mathbf{P \%}$ & K\% \\
\hline $\mathbf{T}_{\mathbf{1}}$ & 1.36 & 0.59 & 1.95 & 0.59 & 0.23 & 1.52 \\
\hline $\mathbf{T}_{\mathbf{2}}$ & 1.05 & 0.54 & 1.86 & 0.50 & 0.20 & 1.50 \\
\hline $\mathbf{T}_{\mathbf{3}}$ & 1.42 & 0.69 & 2.01 & 0.56 & 0.32 & 1.69 \\
\hline $\mathbf{T}_{\mathbf{4}}$ & 1.40 & 0.60 & 1.90 & 0.56 & 0.30 & 1.60 \\
\hline $\mathbf{T}_{\mathbf{5}}$ & 1.63 & 0.70 & 1.92 & 0.67 & 0.39 & 1.63 \\
\hline $\mathbf{T}_{\mathbf{6}}$ & 1.52 & 0.66 & 1.83 & 0.63 & 0.35 & 1.49 \\
\hline $\mathbf{T}_{\mathbf{7}}$ & 1.85 & 0.78 & 1.82 & 0.78 & 0.49 & 1.88 \\
\hline $\mathbf{T}_{\mathbf{8}}$ & 1.63 & 0.73 & 1.93 & 0.67 & 0.40 & 1.77 \\
\hline $\mathbf{T}_{\mathbf{9}}$ & 1.83 & 0.88 & 2.05 & 0.84 & 0.51 & 1.84 \\
\hline $\mathbf{T}_{\mathbf{1 0}}$ & 1.74 & 0.72 & 1.98 & 0.72 & 0.43 & 1.52 \\
\hline $\mathbf{T}_{\mathbf{1 1}}$ & 1.91 & 0.92 & 2.13 & 0.95 & 0.60 & 1.97 \\
\hline $\mathbf{T}_{\mathbf{1 2}}$ & 1.65 & 0.78 & 1.92 & 0.80 & 0.50 & 1.47 \\
\hline L.S.D 5\% & 0.266 & 0.179 & N.S & 0.181 & 0.114 & 0.144 \\
\hline
\end{tabular}

The values of $\mathrm{P}$ and $\mathrm{K}$ concentrations of wheat grain and straw were significantly increased as affected by sources and rules of nitrogen combined with Azolla, yeast and compost tea fertilizer. Higher value of $\mathrm{P}$ and $\mathrm{K}$ concentrations for wheat grain and straw were achieved with the application $T_{11}$ and $T_{9}$ treatments than the other treatments. Increasing nitrogen from 50 to $75 \mathrm{KgFed}^{-1}$ and Azolla, yeast and compost tea enhanced their effect on the studied P \& K elements. The data in Table (4) showed that the application of $\mathrm{T}_{11}$ and $\mathrm{T}_{9}$ resulted in significant effects on the concentration of $\mathrm{P} \& \mathrm{~K}$. The highest value of $\mathrm{P}$ and $\mathrm{K}$ 
concentration of wheat grain were determined with $\mathrm{T}_{11}$ being $0.92 \mathrm{P}$ and $2.13 \mathrm{~K} \%$ for grain and $0.60 \mathrm{P}$ and $1.97 \mathrm{~K} \%$ for straw while application of $\mathrm{T}_{9}$ giving $0.88 \mathrm{P}$ and $2.05 \mathrm{k} \%$ in grain and $0.51-1.84 \mathrm{~K} \%$ in straw. Data in Table ( 4 ) also showed that $\mathrm{P} \& \mathrm{~K}$ concentration in both grain and straw were affected by the treatment which could be arranged as follows: T11> T9 $>$ T7 for all treatments.

Also compost tea application to different rates of urea increased the uptake of the three macronutrients especially the rate of $\left(75 \mathrm{Kg} \mathrm{N} \mathrm{Fed}^{-1}\right)$ in the grain and straw compared with the control $\left(\mathrm{T}_{1}\right.$ and $\left.\mathrm{T}_{2}\right)$ my due to its direct nutrients supplying and / or its microbial function. The recorded values of $\mathrm{N}, \mathrm{P}$ and $\mathrm{K}$ concentration by grains were $1.85,0.78$ and $1.82 \%$ for soil treated with compost tea combination ( $75 \mathrm{~kg} \mathrm{~N} \mathrm{Fed}^{-1}$ ) wherease the straw recorded $0.78,0.49$ and 1.88 \% . ( Al - Kahal et al ., 2009 ). reported that compost tea is concentrated a liquid fertilizer and inoculum of beneficial microorganisms therefore, the simulative effect of compost tea may be attributed to the beneficial microbes present in compost tea. It is postulated by various investigators that microbes in compost bring about the enhancement of plant growth of yield by stimulating the mineralization of organic matter and by solubilizing nutrients tied - up on soil particles which in turn reduce the reliance on chemical fertilizers. Also, microbes extend the root system of plants and thereby improve nutrient uptake, plus increased food storage and soil respire .

\section{Some soil chemical properties of the studied:}

Application of compost tea, Azolla, yeast and different urea rates on some physicochemical saline soil properties after wheat harvesting are mentioned in Table ( 5 ). Inoculation of Azolla, yeast and compost tea are in combination with nitrogen (urea) levels increased the organic matter percentage of the soil over the control treatment $\left(\mathrm{T}_{1}\right)$ after wheat cultivation. The highest organic matter were obtained with application of $\mathrm{T}_{11}, \mathrm{~T}_{12}, \mathrm{~T}_{9}, \mathrm{~T}_{10}$ and $\mathrm{T}_{3}$ being 1.21, 1.11, $0.96 \%$ and $0.96 \%$. This was still higher than all the treatments. The results obtained in the current study are in harmony with_Nazeer_and_Prassad_(1984) who found that, added Azolla with soil builds up organic matter content.

\section{$\mathrm{EC}$ and soil reaction $\mathrm{pH}$ :}

The soil EC in all treatments showed in Table ( 5 ). Application of Azolla and urea $50 \& 75 \mathrm{Kg} \mathrm{N} \mathrm{Fed}^{-1} \mathrm{~T}_{3}$ and $\mathrm{T}_{4}$ slightly decreased the soil EC. $\left(\mathrm{T}_{3} 9.42\right.$ and $\mathrm{T}_{4}$ 9.62) as compared with the treatments $\mathrm{T}_{9}(9.74)$. The use of treatments $\mathrm{T}_{11}$ and $\mathrm{T}_{12}$ decreased the soil $\mathrm{EC}\left(\mathrm{T}_{11}: 8.79\right.$ and $\left.\mathrm{T}_{12}: 8.80\right)$ than the other tested treatments and also as compared to the soil before wheat cultivation. These results were in harmony with EL-Berashi (2008) reported that the soil EC were slightly decrease than the control treatments. 
The effect of applying Azolla, yeast and compost tea in $\mathrm{pH}$ of the soil saline in table (5). Application of $\mathrm{T}_{11}, \mathrm{~T}_{12}$ and $\mathrm{T}_{10}$ slightly decrease the soil $\mathrm{pH}$. The results in table (5)showed that the use of Azolla, yeast and compost tea $\mathrm{T}_{11}, \mathrm{~T}_{12}$, $\mathrm{T}_{3}, \mathrm{~T}_{4}$ and $\mathrm{T}_{10}$ decreased the soil $\mathrm{pH}(7.43,7.30,7.50,7.63$ and 7.7) than all treatments and also as compared to the soil $\mathrm{pH}$ before wheat cultivation, these results were in harmony with EL-Shahat et al. (2007) who found that incorporation of Azolla decreased the soil $\mathrm{pH}$.

\section{Macronutrients content in soil.}

Data showed in Table (5) revealed that, plant treated with $\mathrm{T}_{11}$ exhibited the highest mean values of $\mathrm{N}, \mathrm{P}$ and $\mathrm{K}$ than other treatments, Treatment $\mathrm{T}_{11}$ is considered as an available medium for most of beneficial microorganisms including nitrogen fixers, phosphorus and potassium solubilizing . Application of $\mathrm{T}_{11}$ play an important role of enhancing Cyanobacteria and bacterial count to fix more atmospheric nitrogen which reflected on the increase of $\mathrm{N}$ content in the soil. The same trend was observed with the increase of $\mathrm{P}$ and $\mathrm{K}$ solubilizing where they both led to increase of $\mathrm{P}$ and $\mathrm{K}$ contents.

Data in Table (5) showed that, nitrogen, phosphorus and potassium soil content were significantly increased when application $\mathrm{T}_{11}$ over all treatments. However the highest NPK content were $114.50,6.18$ and 245 ppm respectively. This trend was previously confirmed by Abd El - Baky et al ., (2008 ) who reported that spraying wheat cultivated under salt stress condition with algae extracts increased the NPK content compaered to those received $100 \% \mathrm{~N}$ dose without algal extract spraying. These finding were observed by Strik and Staden (2003) who explained that, incorporation of fresh or dry Azolla into soil increased significantly the soil organic matter, which in turn upon its decomposition by the soil microorganisms had released the macro and micronutrients into soil, leading to increase the soil available nitrogen.

Macronutrients N,P and $\mathrm{K}$ availability in the studied saline soil presented in table $(5)$. Application of treatments $\mathrm{T}_{11}$ and $\mathrm{T}_{9}$ were statistically significant by increased in N,P and $\mathrm{K}$ as compared to all tested treatments, data in Table ( 5 ) showed that treatment including Azolla, yeast, compost tea and $75 \mathrm{Kg} \mathrm{N}$ Fed $^{-1}$ $\left(\mathrm{T}_{11}\right)$ gave the highest records of $\mathrm{N}, \mathrm{P}$, and $\mathrm{K}$ content giving $114.5 \mathrm{~N}, 6.18 \mathrm{P}$ and $245 \mathrm{~K}$ ppm.

Data in Table (5) showed combination of compost tea with different rate of urea $\left(\mathrm{T}_{7}, \mathrm{~T}_{8}\right)$ increased organic matter and decreased $\mathrm{PH}$ and $\mathrm{EC}$ and raised the availability of $\mathrm{N}, \mathrm{P}$ and $\mathrm{K}$ over the control treatment. In general, it may be concluded that compost application increased soil organic matter, $\mathrm{Ca}^{2+}, \mathrm{Mg}^{2+}, \mathrm{K}^{+}$ and $\mathrm{P}$ while $\mathrm{C}: \mathrm{N}$ ratio was narrowed in acidic soil. Hence, there was a general increase in nutrient supplying capacity of soils ( Sarwar al et., 2010 ). 
Table (5): Effect of application, of compost tea, Azolla and yeast on some physicochemical properties of soil after wheat harvesting (data are means of two seasons)

\begin{tabular}{|c|c|c|c|c|c|c|}
\hline \multirow{2}{*}{ Treatments } & \multirow{2}{*}{ O.M \% } & \multirow{2}{*}{ E.C \% } & \multirow{2}{*}{$\mathbf{p H}$} & \multicolumn{3}{|c|}{ Macronutrients ( ppm ) } \\
\cline { 5 - 7 } & & & $\mathbf{N}$ & $\mathbf{P}$ & $\mathbf{K}$ \\
\hline $\mathbf{T}_{\mathbf{0}}$ & 0.64 & 11.70 & 8.25 & 64 & 4.89 & 177 \\
\hline $\mathbf{T}_{\mathbf{1}}$ & 0.66 & 11.80 & 8.26 & 66 & 5.03 & 179 \\
\hline $\mathbf{T}_{\mathbf{2}}$ & 0.65 & 11.80 & 8.23 & 63 & 4.90 & 183 \\
\hline $\mathbf{T}_{\mathbf{3}}$ & 0.96 & 9.42 & 7.50 & 79 & 5.11 & 211 \\
\hline $\mathbf{T}_{\mathbf{4}}$ & 0.86 & 9.62 & 7.63 & 65 & 5.18 & 206 \\
\hline $\mathbf{T}_{\mathbf{5}}$ & 0.74 & 11.60 & 8.10 & 68 & 4.96 & 185 \\
\hline $\mathbf{T}_{\mathbf{6}}$ & 0.79 & 11.60 & 8.05 & 68 & 4.80 & 179 \\
\hline $\mathbf{T}_{\mathbf{7}}$ & 0.78 & 11.45 & 7.92 & 81.1 & 5.22 & 206 \\
\hline $\mathbf{T}_{\mathbf{8}}$ & 0.81 & 11.55 & 7.86 & 70.1 & 5.08 & 200 \\
\hline $\mathbf{T}_{\mathbf{9}}$ & 0.96 & 9.74 & 7.50 & 99.18 & 6.04 & 221 \\
\hline $\mathbf{T}_{\mathbf{1 0}}$ & 0.96 & 10.04 & 7.70 & 86.20 & 5.03 & 219 \\
\hline $\mathbf{T}_{\mathbf{1 1}}$ & 1.21 & 8.79 & 7.43 & 114.50 & 6.18 & 245 \\
\hline $\mathbf{T}_{\mathbf{1 2}}$ & 1.11 & 8.80 & 7.50 & 95.35 & 5.60 & 210 \\
\hline
\end{tabular}

\section{Conclusion}

The application of compost tea , Azolla and yeast in wheat cultivation can be considered as a promising technique bot to increase the wheat production and to provide protection from the environmental pollution caused by the extensive use of chemical fertilizers. Thus it may be inferred that compost tea, Azolla and yeast exhibited a better $\mathrm{N}$ availability to wheat than urea and it could act as a substitute nitrogen source for many crops other than urea.

\section{References}

Abd El- Rasoul, Sh.; Mona M.; Hanna, H. ; Elham; Aref, M. and Ghazal, F. M. (2004). Cyanobacteria and effective microorganisms ( EM ) as possible biofertilizers in wheat production. J. Agric. Mansoura Univ., 29 : 2783 - 2793.

Al - Kahal, A. A.; Ahmed, S.M.; Saleh, W. D. and G. A. M. El - Sayed. (2009). Productivity of clover as affected by application of compost tea. Egypt. J. of Appl. Sci., 24 (3B): 807 - 817.

Allen, M. M. and Stanier, R. Y. (1968). Selective isolation of blue - green algae from water and soil. J. Gen. Microbiol., 51: 203 - 209. 
Amer, S. A. (2004). Growth, green pods yield and seeds yield of common Bean (Phoseolus vulgaris $L$. ) as affected by active dry yeast, salicylic acid and their interaction. J . Agric Sci. Mansoura Univ ., 29 ( 3 ) : 1407 - 1422 .

Awodun, M. A. (2008). Effect of Azolla ( Azolla species ) on physiochemical properties of soil . World. J. of Agric. Sci., 4 (2): 157 - 160.

Black, C. A. (1965). In "Methods of Soil Analysis" Amer. Soc. Of Agron. Inc Pub. Madison, Wisconsin, USA.

Casida, L.E. ; Klein, D.A. and Santof, T. (1964). Soil dehydrogenase activity. Soil Sci., 98 : 371 - 376.

Chapman, H. D. and Pratt, P. F. (1961). Methods of Analysis for Soils, Plant and water. Agric. Publ. Univ., of California, Reverside.

Dauda, S. N.; Ajayi, F. A. and Ndor, E. (2008). Growth and yield of water melon ( Citrullus lanatus ) as affected by poultry manure application . $J$. Agric. Soc. Sci., 4: 121 - 124.

El- Berashi, M. (2008). Impact of Azolla in increasing rice production and reducing environment pollution. Ph. D. Thesis in Sciences Dept. of Agric. Sci., Inst. of Environ. Studies and Res. Ain Shams Univ. pp. 140 - 152.

El - Howeity, M. A.; Omar, N. M. A.; EL- Shinnawe, M. M. and Aboel Naga. S. A (2004). Colonization pattern of some diazotrophs on wheat and Maize, roots in vitro and in vivo experiments. Eleventh, CONF. MICROBIOL., Cairo, Egypt, Oct. 18 - 19 pp.

El - Shahat, M. R. (2007). Cyanobacteria can compensate a part of mineral nitrogen required for wheat production. J . Agric. Sci . Monsoura . Univ ., 32 ( 2 ) : 1367 - 1377.

El - Zeky, M. M.; El - Shahat, R.M. ; Metwaly, Gh. S. and El - Ham, M.A. (2005). Using of cyanobacteria or Azolla as alternative nitrogen sources for rice production. J. Agric. Sci. Mansoura, Univ., 30: 3367 - 5577.

Ezz EI - Din, A. A. and Hendawy, S. F. (2010). Effect of dry yeast and compost tea on growth and oil content of Borago officinalis plant. Res. J. Agric. Biol. Sci., 6 (4): $424-430$.

Gaur, A. C.; Sadasivan, K. V.; Vitumal, O. P. and Mathur, R.S. (1971). A study of decomposition of organic matter in an alluvial soil, Co2 evolution mycological and chemical transformation. Plant and soil, 34: $17-28$.

Gomez, K . A. and Gomez, A. A. (1984). A Statistical Procedures for agricultural research (2 ${ }^{\text {nd }}$ ed .) , International Rice Research Institute, P.O.B. 933, Los Bnos, Manilla , Phlippines . pp. 20 - 29 \& 359 / 387 .

Hardy, F. N.E.; Burns, R.C. and Holsten, R.D. (1973). Application of the acetylene - ethylene assay for measurement of nitrogen fixation. Soil, Biol. Biochem. 5: 47 - 81.

Hendawy, S.F.; Azza, A.; Ezz El - Din, Eman E.; Aziz and Omar, E .A. (2010). Productivity an oil quality of Thymus vulgaris under organic fertilization conditions. Ozean J. of App. Sci., 3 (2): 203 - 215.

Egyptian J. of Phycol. Vol. 13, $2012 \quad \mathbf{- 8 8}$ - 
Hoitink, H. A. J. and Grebus, M.E. (1994). Status of biological control of plant disease with composts. Compost Sci. Utilization, 2: 5 - 12.

Ingham, E. (2005). The compost tea brewing manual. US printings . Soil Foodweb Incorporated, ovegon.

Jackson, M. L. (1976). Soil Chemical Analysis. Constable, Co. Lt., London.

Kheder, Z. M. and Farid, S. (2000). Response of naturally virus infected plants to yeast extract and phosphoric acid application . Ann. Sci. Moshtohor, Egypt., 38: 927 - 939.

Kurtzman, C . P . (2005). Biodiversity and E cophysiology of yeasts ( In : The Yeast Hand Book, Gobor P, de La Rosa CL, eds ) Berlin, Springer, 11 / 30 .

Mandal, P. L.; Velk, P.L.G. and Mandal, L.N. (1999). Beneficial effect of blue - green algae and Azolla excluding supplying nitrogen. On wetland rice filds : a review. Biol. Fertil. Soils, 28: 329 - 342.

Naguib, N.Y.M. (2011), Organic v.s chemical fertilization of medicinal plant : a concise review of researches. Adv. Environ. Biol., 5 (2): 394 - 400.

Nazeer, M . and Prassad , N . (1984). Effect of Azolla application on rice yield and soil properties phykos. 23: 1, $269-272$.

Norton, R. D. (2004). Agricultural Development policy : Concepts and Experiences. Jon Wiley and Sons, Ltd. Ny. 528P.

Reda M. EI - Shahat ; Hanaa A.; Abo - Kora and El - Hossiny E. E. Khafaga (2011) . Azolla inoculant contribution to improve some soil properties and zea mays yield in saline soil. Egypt. J . Biotechnol., 37: 69-81.

Rao, D. L.N. and Burns, R. G. (1990). The effect of surface growth of blue green algae and bryophytes on some microbiological, biochemical and physical soil properties. Biol. And Fertil. Soils, 9: 239 - 244.

Sarwar, G; Schmeisky, H.; Tahir, A.; Iftikhar, Y. and Sabah, N. (2010). Application of green compost for improvement in soil chemical properties and fertility status. Journal of Animal and Plant Sciences. 20 (4): 258 260.

Shahram, S. and Kourosh, O. (2011). Organic and Biofertilizers as a good substitute for inorganic fertilizers in medicinal plants farming. Journal of Basic and Applied sciences, 5 (12): 1330 - 1333.

Strik, W. A. and Staden, J. V. (2003). Occurrence of cytokinin - like compounds in two aquatic fern and their exudates. Environ. Exp. Botany, 37: $569-571$.

Suresh, K. D.; Sneh, G.; Krishn, K. K. and Mool, C. M. (2004). Microbical biomass carbon and microbial activities of soils receiving chemical fertilizers and organic amendments. Arch. Agron. Soil Sci., 50: 641 647. 
Tilak, K . V. B. R. and Reddy, B. S. (2006). B. cereus and B. circulans novel inoculants for crops. Curr. Sci., 5: $642-644$.

Vincent, J. M. (1970). A manual for practical study of root - nodule bacteria IBP Hand book, No 15, Blackwell Sci., Pub., Ltd., Oxford and Edinburgh UK.

Zaka, M. A.; Mujeeb, F.; Sarwar G. and N. M. Hassan, (2003). Agromelioration of saline sodic soils . J. Biol. Sci., 3 (3): 329 - 334.

\title{
ثأثثير شاى الكمبوست ، الأزولا والخميرة على محصول القمح فى الأرض الملحية
}

\author{
آمال إبراهيم حنا ، رضا محمد الشحات ، منيرة معوض بشارة \\ معهد بحوث الأراضى والمياه والبيئة. مركز البحوث الزراعية. الجيزة. القاهة
}

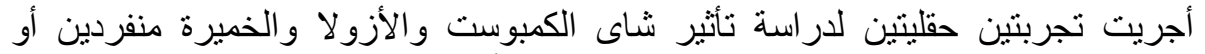

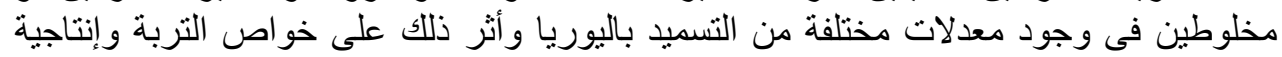

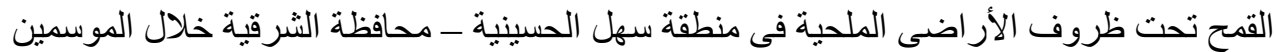

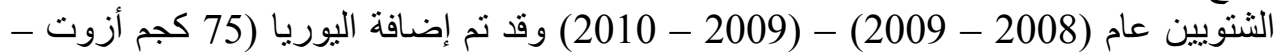

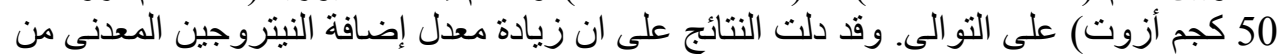

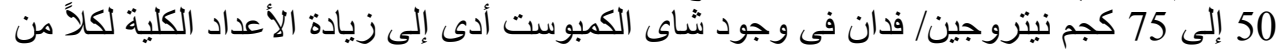

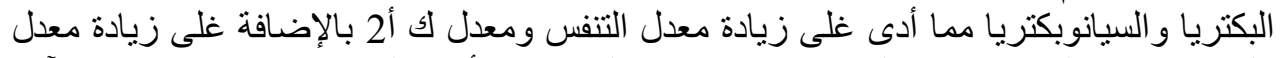

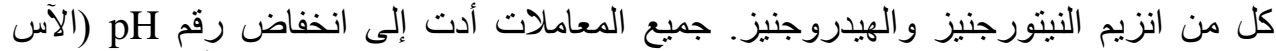

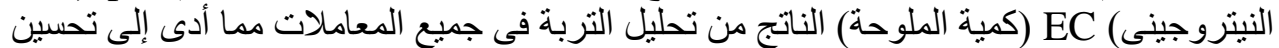

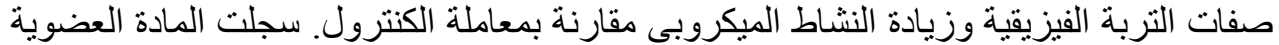

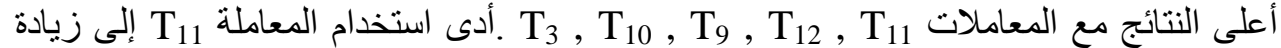

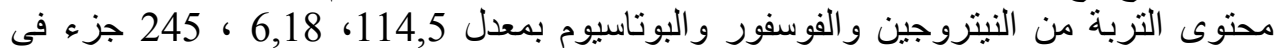

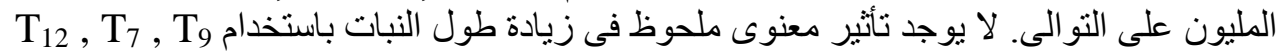

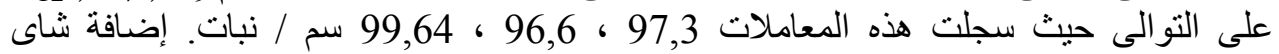

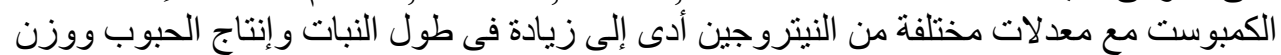

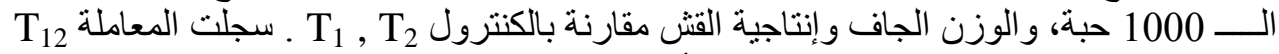

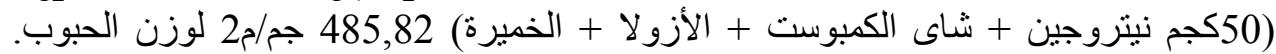

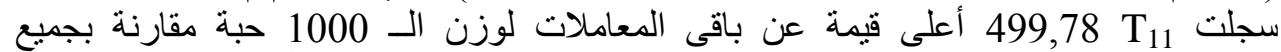

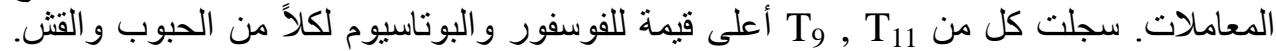
سجلت التربة المعاملة بشاى الكمبوست ، 75 كجم نبتروجين للفدان أعلى تركيز اللفئ للنيتروجين

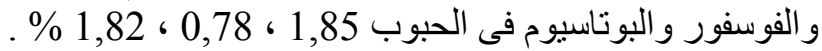

